\title{
Potential for Intermodal Transport of Chemical Goods in Slovakia
}

\author{
Juraj Jagelčák ${ }^{1, *}$, Ján Zámečník ${ }^{1}$, and Monika Kiktová ${ }^{1}$ \\ ${ }^{1}$ University of Žilina, Faculty of Operation and Economics of Transport and Communications \\ Department of Road and Urban transport, Univerzitná 1, 01026 Žilina, Slovak Republic
}

\begin{abstract}
This article deals with intermodal transport of chemical goods in Slovak republic. Analysis is based on information from interviews with companies and logistics service providers. The first part of the article describes importance of Intermodal transport and basic transport routes for intermodal transport. Respondents considered advantages and disadvantages of intermodal transport. Possible improvements inside companies and improvements of external framework conditions to promote modal shift are described in the second part of the paper.
\end{abstract}

\section{Introduction}

This paper was completed with information from interviews with 5 manufacturing companies and 6 logistics service providers (LSP). It is necessary to say that many companies are not willing to provide related information because they consider them as confidential business data.

Bigger industrial enterprises evaluate the importance of intermodal transport as significant. Intermodal transport is also a perspective solution for future due to actual situation of transport market. There are several problems in the field of road transport such as lack of drivers with worsening trend (less attractive of the profession due to its characteristics - long time away from home, safety and security risks [1-4], high costs for driver licence and qualification card,...) or increase of costs (toll, minimum wages in some of the European countries,...). As an additional problem (as is resulting from the statistics mentioned above) can be mentioned the differences between export and import cargo flows [5] from/to particular European countries, resulting to problematic backhaul. Therefore, a lack of free vehicles for the cargo may occur as a result of these factors (worse availability of some types of vehicles, e.g. tank vehicles). Using of intermodal transport may cover intended transport amount growth in future. Intermodal transport is important mainly for long-distance transports [6-8] and for oversea transports. The individual relations where the intermodal transport using brings an advantage depend on offer of intermodal connections [6-9]. Existing intermodal services are mainly focused on transport to the important European maritime ports - Hamburg, Rotterdam, Koper, Bremerhaven, so the overseas transport over these ports is mostly done intermodal [6] and on the other hand, the overseas

* Corresponding author: juraj.jagelcak@,fpedas.uniza.sk 
transport play an important role in performances of intermodal transport. The lower transport costs are reached by using the intermodal transport in these relations and transit time is also favourable. One of the respondents expressed that some of the production sites depend on the intermodal lines for their productions, as they are $100 \%$ supplied by intermodal transport [9]. Among further important benefits stated by the respondents can be mentioned moving storage forward in the chain = having a warehouse closer to production sites allowing for safety stock and better lead times between order and delivery [9] and intermodal transports are still done during holidays, such as the x-mas / new year period which is a dangerous period for the supply chain of some sites. Ships and trains will still go, so shipments by container are a huge benefit in that period [6].

\section{Important Transport Routes}

An offer of intermodal lines is an important factor of potential of using intermodal transport. The most important intermodal operators in Slovakia are Metrans, a. s. and Rail Cargo Operator - CSKD, s. r. o. They operate mainly a container trains to/from maritime ports, although some continental lines are also available. The respondents - industrial companies named following intermodal transport routes which they use or consider as a potential for intermodal transports to ports Hamburg, Koper, Rotterdam, for transport of $45 \mathrm{ft}$ units [10] to England, to south France/north Spain, from north Slovakia to north Germany - other than ports, from Slovakia to Turkey (save 2 days - min. risk), North West Slovakia - mid UK, S̆al'a (SK) - North UK, North Portugal and North Spain, Belgium Malacky - Terminal Dunajska Streda. However, significant part of transports are the transports to neighbouring countries. Using of intermodal transport to these countries is not so advantageous due to shorter distances [11] and not well-developed network of intermodal terminals. If intermodal transports to neighbouring countries with a transport distance about $500 \mathrm{~km}$ would be used, using of cranable semitrailers should be more suitable than system based on containers - but terminals in Slovakia are not equipped to handling them. If we talk about Balkan countries (Romania, Bulgaria, Serbia), offer of intermodal rail lines to these countries is very limited yet [6]. But the amount of international trade with these countries is less than that with West-European countries.

\section{Potential for modal shift}

Respondents - industrial companies and distributors of chemicals reported such share of intermodal/intermodal transport on total transport performances is $8 \% ; 12 \%$; $32 \%$; approx. $50 \%$ of inbound deliveries. One respondent reported the share of intermodal transport as very low within Slovakia (but having higher level in other countries). In presence, the respondents use intermodal transport in these routes from/to marine ports - 5 $7 \%$ of transport volume, marine containers from/to company by truck/single wagons, transport of raw materials - import from places out of Europe, transport of semitrailers of ferries from ports in Germany to Scandinavian countries (Norway, Sweden, Finland) as well as between ports in Denmark and the United Kingdom (used in approx. $15 \%$ of transports performed by the respondent company), intermodal transport of semitrailers by rail in relations Denmark - Austria/Italy, Sweden - Norway, Norway - the Netherlands.

Overseas transports of chemical commodities are already performed mostly intermodal using containers (existing intermodal services to important European ports are welldeveloped), alternatively using block trains and reloading in port terminals in case of largequantity bulk substrates. New potential of growth is therefore mainly in continental intermodal transports. Main motivation for modal shift from road to rail transport by the 
enterprises' point of view is in these fields in the field of transport to/from marine ports, Nordic countries road-rail-sea (cost and transit time advantages), for transport to/from Turkey, higher efficiency for heavy goods. Maximum allowed weight of road combination used in intermodal transport is 44 tonnes (versus 40 tonnes in direct road transport) according to Slovak legislation. This becomes an advantage mainly when cranable semitrailers are used as ILU, because a difference of tare weight (curb weight) between cranable and standard semitrailer is much lower than a tare weight of container/swap body, therefore the payload of cranable semitrailer is higher (up to 29 tonnes). But following limiting factors have to be considered as load distribution on axles of tractor and semitrailer (this has to be considered even before loading a container/swap body, because a distribution of cargo in ILU affects position of ILU's centre of gravity and subsequently distribution of load on particular axles of road vehicle carrying the ILU) [10] and maximum mass of road combination allowed also in the destination (origin) country on the other side of transport chain. The Council Directive 2015/719/EU prescribes mass 42 tonnes in intermodal transport of containers and swap bodies by standard combinations with 2 -axle tractors. The Council Directive does not prescribe any higher weight limit than usual 40-tonne limit for transport of cranable semitrailers within intermodal transport).

Another aspects are better situation with free capacities of intermodal transport in comparison with road transport (which is affected by lack of drivers, tank vehicles...). Companies consider intermodal transport as a perspective solution which can cover intended production growth in future. However, there is a deficit of intermodal transport units (containers) in presence yet.

The respondents consider mainly the following routes as perspective to shift transport from road to intermodal for trains from Zilina to north Germany - one time per week, Ruzomberok to Germany, Czech republic, Italy - one train per week, from west Slovakia/Bratislava to France, from Sala to South France / North Spain, from southwest Slovakia to Ludwigshafen (DE), Colmar-Berg (LUX).

One of the respondents see a potential also in transport of cargo from Ukraine to Europe due to advantage - elimination of delays of trucks on border crossing. A problem is, that amount of international trade between Slovakia and Ukraine (as well as other eastEuropean countries) is low (if we do not take imports of bulk raw materials such as crude oil, natural gas or iron ore into account - such commodities are unsuitable for intermodal transports). Moreover, east-European countries of former USSR have different railway gauge $(1520 \mathrm{~mm})$. Intermodal services can be efficiently operated only when a sufficient amount of cargo flow (optimally - sufficient for operating several trains per week due to flexibility) exists to/from particular region in some of these countries (area surrounding a terminal up to approx. $150 \mathrm{~km}$ ). We have also take into account that travelling speed in railways in east-European countries are lower than those reached in west-European railways [12]. The same situation is in Balkan countries.

One of the respondents see also a potential for perspective extension of intermodal transport using as a possibility of deliveries to customers - motivated by lack of tank vehicles.

A respondent - intermodal operator see a potential of intermodal transport for dangerous goods transport due to safety improvement (lower risk of accidents, better safety of road traffic) and simplified handling with dangerous goods transported in tank containers.

\section{Benefits and advantages of Intermodal transport}

The respondents reported mainly lower costs, sufficient free capacities also shorter transit time in specific routes as key advantages of intermodal transport. They considered environmental and social responsibility aspects as less important factors. In general, the 
advantages of intermodal transport were considered as lower transport costs, regular connection, short transit time in specific relations or periods (e.g. around Christmas), good transport capacity, possibility of transport $45 \mathrm{ft}$ containers, ability to supply sites despite of holiday restrictions, allowing to setup safety stock closer to production sites, possibility of using of additional services such as issuing VGM declaration in terminals, it is the only one possibility if vendors/consignees are located outside Europe, diversification of transport modes, higher efficiency for heavy goods in relation with higher allowed weight of trucks. This is an advantage mainly in intermodal transport using portable semitrailers with higher payload, better safety of dangerous goods transport, better quality of transport services to localities covered by well-developed and advantageous intermodal services. One of the respondents referred that intermodal transport is more flexible in comparison with road transport for its purposes due to lack of tank vehicles. Intermodal transport does not have to be arranged several weeks in advance. In general, it can be said that companies in Slovakia focus on the lowest prices much more than on conceptual solutions.

\section{Barriers and disadvantages of Intermodal transport}

As barriers and disadvantages of multimodal transport shall be considered lack f ILU's for modal shift; small motivation of road hauliers for modal shift; small motivation to buy cranable semitrailers; lack of ILU's for packed load in Europe; strong difference between export and import flows - therefore missing backhaul of intermodal transport units; longer transport duration in comparison with the road transport in many cases. It relates mainly with transports to shorter distances.

Further barriers are destination without direct connection (services) or less frequented intermodal services. There is not well-developed network of intermodal terminals in some regions related with transit duration and costs, longer road pre-carriage/on-carriage is needed. Total distance of transport becomes longer and costs become higher.

Lack of intermodal terminals is another barrier because most of the terminals in Slovakia are located in the southwest and southeast. Only the terminal in Žilina with limited extension possibilities (due to location in city centre) is available. Further terminal in Žilina - Teplička is not operated yet. The terminal in Ružomberok (close to cellulose plant) is almost unused. Some regions of Slovakia (north and northeast, south part of middleSlovakia) are quite far from the intermodal terminals and motorways in these regions are not developed.

Further barriers is delay probability which is not lower than for road transport, but the effect is higher. Sometime there is a sufficient cargo volume but the costs for intermodal transport are simply too high.

Local legislation and restrictions e.g.:

- France: limited corridors for intermodal transport,

- allowed weight of road vehicles (and as a result - weight of cargo in ILU) is different in particular countries, not allowing optimization of the load unit. This factor limits possibility of practical use of higher payload of cranable semitrailers, because maximum allowed weight of road combination has to be followed both in the country of origin and the country of destination;

Other barriers:

- transport document do not always accompany the cargo or container when handled at a terminal;

- $\quad$ missing flexibility - a shipper is mostly bound to one operator or its partners;

- risk of failure to comply with the delivery time in case of just-in-time deliveries;

- the solution is heavily dependent on backflow; 
- some destinations are not covered with intermodal services (France, Spain, Scandinavia, Balkan, middle and south Italy, localities in northeast part of Germany) not covered at all or not in sufficient frequency which considerably determines flexibility and door-to-door transport time;

- a significant part of cargo flows to/from Slovakia bounds to/from neighbouring countries and using of intermodal transport is not advantageous for shippers (due to costs and transit time);

- if no suitable (direct) intermodal service is available, transport costs may be higher. The same situation is in case of short-distance transports;

- for products carried at elevated temperature - longer transit times cause a need to heating up before discharging;

- some of terminals haven't conditions for chemical goods - storage of dangerous goods is restricted;

- System of single wagon or group of wagons isn't applicable - complicated arrangement, long transport duration, higher risk of cargo damaging due to shunting shocks...[12];

- high financial amount (investments) is needed to acquisition of special equipment needed for intermodal transport operation without any guarantees of sufficient amount of transported cargo.

\section{Possible Improvements inside companies to promote modal shift}

Industrial companies reported following proposals to promote modal shift/extent the use of intermodal transport:

- $\quad$ expand sales to overseas countries (it would result into growth of traffic mainly on existing intermodal lines to maritime ports);

- modal shift from road to intermodal transport in regular relations of supply/distribution, which are simply accessible from intermodal terminals and do not need just-in-time deliveries;

- exchange of experience with start of terminal operation in company and transhipment systems;

- intermodal transports other than intermodal (loading of wagons in a production site on a railway siding - rail transport to warehouse in destination country - storage - road transport to final consignees) are complicated in logistics - operation of warehouses, transhipment of cargo in localities close to consignees etc. There are following possibilities to use intermodal transport:

○ using of intermodal terminals close to a site of consignor/consignee,

- bigger production sites can also load/unload containers at the own area on railway sidings using own handling equipment. As an example can be mentioned the container side lifter used in one chemical company. Such type of handling equipment is suitable for operation in industrial areas due to its flexibility, lower space needed for handling in comparison with cranes or reach stackers operating in terminals.

- The companies in which the share of intermodal transport is already big, identify no further significant possibility for further increase of the share, because they already use intermodal transport where it is economically efficient. They have already attempted many different options to increase intermodality - the only limitation are costs. There needs to be a saving which is not always the case for transport routes which they investigate for. New depots are also required to be able to (off)load containers. 
Logistics services providers reported following proposals for the improvement of modal shift:

- help with organisation of transhipment/operation of wagons/tank containers,

- ongoing (year on year out) investments into vehicle and wagon fleet suitable for intermodal transport,

- improvement of additional services offer - services in customs clearance, building, extending and modernization of intermodal terminals, modernization of terminal equipment, new locomotives for shorter transit durations, providing VGM declaration services.

\section{Possible Improvements of external framework conditions to promote modal shift}

Industrial companies propose to exchange experiences for start of transhipment - e. g. more chemicals companies became interested for system of side loaders; to improve loading capabilities of containers or other modalities at primary loading sites, and onsite intermodal terminal eliminating a shuttle transport between primary loading site and a railway/shipping terminal; lower railway infrastructure fee for intermodal transport; to establish state support of building company transhipment sites in areas of industrial enterprises (primary loading sites), acquisition of handling equipment etc. with grants; more support engaging of individual containers into block trains $\rightarrow$ motivate national rail operators and important private operators; to improve accessibility of intermodal terminals for road transport including remote marking of access routes; to complete missing intermodal terminals in some regions; to support construction of terminals and acquisition of handling equipment by state grants which is currently not enough (Higher support is e.g. in Czech republic (up to $50 \%$ of costs) which brings better efficiency.).

From logistics service providers point of view there is a necessity of state investments into modernisation and improvement of infrastructure - enough capacity and speed has significant influence on transport duration.

\section{Conclusion}

A situation with intermodal transport and its use for transport of chemical goods is very similar in middle-European countries. Production sites of chemical industry (=sources of chemical goods transports) are usually relatively large and many of them are equipped with railway sidings. Intermodal transport is used mainly for transports from/to seaports within overseas transports in presence. Such transports are, in the field of chemical goods, already performed mostly intermodal and a potential of future growth is only in extension of amount of overseas transport in general. A better potential for intermodal transports growth is in continental transports for longer distances. Such potential is limited by shortcomings in offer. Existing services are focused mainly on seaports and partially on some centres in Rhine and Ruhr region, north Italy, Turkey etc. There is a lack of intermodal services to other regions (France, Spain, Great Britain, some regions in Germany, Balkan countries etc.) - where the connections from Slovakia are complicated or completely missing. There is also a lack of intermodal loading units (containers, swap bodies, intermodal trailers) for continental transports and an intermodal system of cranable semitrailers is not developed in Slovakia yet because some terminals in Slovakia are not equipped with handling devices and there is a lack of suitable wagons. Better situation is in continental transports of tank 
containers, where the respondent reports higher availability of capacities and better flexibility of intermodal transport in comparison with road transport.

The main factors causing the enterprises are willing to use intermodal transport are lower costs and/or favourable carriage-operational factors. Most of the enterprises expect longer transport duration of intermodal transport in comparison with road transport. But there are some specific cases in which the intermodal transport may reach shorter transport duration (e.g. in case of long transport distance, in relation with restrictions in road transport during weekends, public holidays, which do not apply on intermodal transport). Other aspects such as safety or environmental aspects are in general considered as less important for making decision about transport mode.

Following proposals resulting from previous analyses can be presented on behalf of ZCHFP SR (The Association of Chemical and Pharmaceutical Industry of the Slovak republic).

It is necessary to improve the offer of intermodal transport units for chemical goods portable tanks, containers. It is necessary to create a support for a system of transport of cranable semitrailer by rail - this intermodal system is not developed in Slovakia yet. Because mostly large enterprises, equipped with railway sidings, operate in the field of chemical industry, it is suitable to improve and develop possibilities of transhipment rail road in companies. This also solves a problem of dangerous goods storage limitations/prohibitions in some intermodal terminals.

This paper is supported by the research project "From horse-drawn railway to intermodal transport" within Visegrad Fund.

\section{References}

1 J. Zamecnik, J. Jagelcak, S.S. Peterssen, Communications: scientific letters of the University of Žilina 18, 2, 76-82 (2016)

2 J. Vrabel, J. Jagelcak, J. Zamecnik, Caban, Procedia Engineering 187 (2017)

3 T- Skrúcaný, et al., DYN-WIND'2017 (MATEC web of conferences 107, 00072, 2017)

4 J. Kubáňová, B. Poliaková, Transport Means 2016 - 20th International Scientific Conference on Transport Means, 22-26 (Juodkrante, Lithuania, 2016)

5 O.Stopka, M. Chovancová, J. Ližbetin, V. Klapita, Naše more 63, 3, 195-199 (2016)

6 J. Ližbetin, J. Ponický, V. Zitrický, Naše more 63, 3, 161-169 (2016)

7 J. Ližbetin, O. Stopka, V. Cempírek, Naše more 63, 3, 156-160 (2016)

8 J. Kubanova, C. Schmidt, Communications: Scientific letters of the University of Žilina 18, 2, 104-108 (2016)

9 I. Kubasakova, J. Jagelcak. Communications: scientific letters of the University of Žilina 18, 2, 109-112 (2016)

10 J. Jagelčák, I. Kubasáková, Naše more 61, 5-6, 106-116 (2014)

11 R. Rievaj et al., Communications: scientific letters of the University of Žilina 18, 2, 57-61 (2016)

12 J. Zamecnik, J. Jagelcak, Communications: scientific letters of the University of Žilina 17, 4, 21-27 (2015) 